\title{
Application of DVC-FISH method in tracking Escherichia coli in drinking water distribution networks
}

\author{
L. Mezule, S. Larsson, and T. Juhna \\ Department of Water Engineering and Technology, Riga Technical University, Azenes 16/20-263, Riga, Latvia \\ Correspondence to: L. Mezule (linda.mezule@rtu.lv)
}

Received: 1 September 2012 - Published in Drink. Water Eng. Sci. Discuss.: 26 September 2012

Revised: 24 December 2012 - Accepted: 13 March 2013 - Published: 2 April 2013

\begin{abstract}
Sporadic detection of live (viable) Escherichia coli in drinking water and biofilm with molecular methods but not with standard plate counts has raised concerns about the reliability of this indicator in the surveillance of drinking water safety. The aim of this study was to determine spatial distribution of different viability forms of $E$. coli in a drinking water distribution system which complies with European Drinking Water Directive (98/83/EC). For two years coupons (two week old) and pre-concentrated (100 times with ultrafilters) water samples were collected after treatment plants and from four sites in the distribution network at several distances. The samples were analyzed for total, viable (able to divide as DVC-FISH positive) and cultivable E. coli. The results showed that low numbers of $E$. coli enters the distribution sytem from the treatment plants and tend to accumulate in the biofilm of water distribution system. Almost all of the samples contained metabolically active $E$. coli in the range of 1 to 50 cells per litre or $\mathrm{cm}^{2}$ which represented approximately $53 \%$ of all $E$. coli detected. The amount of viable $E$. coli significantly increased into the network irrespective of the season.
\end{abstract}

The study has shown that DVC-FISH method in combination with water pre-concentration and biofilm sampling allows to better understand the behaviour of $E$. coli in water distribution networks, thus, it provides new evidences for water safety control.

\section{Introduction}

Over the last century, monitoring of Escherichia coli by using standard plate count methods in water samples taken from several locations of water supply system (grab sampling) has allowed to increase the safety of public water supply system and significantly reduce the mortality caused by waterborne outbreaks in the developed countries. However, this strategy has not been always successful in detecting outbreaks, including several major ones (Lee et al., 2002). This approach has not also been able to explain sporadic contamination cases of drinking water (Hunter, 1997). There are several reasons for this bias including the following ones: (i) due to different rates of transport in aquatic environment and resistance to disinfection, the presence of $E$. coli does not always correlate with other pathogens (Ashbolt et al., 2001), (ii) some E. coli cells could be injured or stressed and un- able to reproduce on growth media used for their detection (Scheusner et al., 1971) and (iii) the probability of detecting the contamination with grab sampling is low due to the small size of samples and limited sampling locations in the networks (van Lieverloo et al., 2007). The significance of the latter two factors in the context of understanding the fate of E. coli is only marginally studied.

Although it is still disputable whether so called viable but not cultivable (VBNC) state of bacteria actually exist (Bogosian et al., 1998), there are convincing evidences that not all alive (viable) E. coli are able to form colonies in the conditions used for standard plate counting (growth media, temperature, cultivation time) ( $\mathrm{Na}$ et al., 2006). The importance of this bacterial subpopulation for public health is stressed by numerous molecular studies showing that they still retain ability of gene expression (Asakura et al., 2007; Oliver, 2010) including the ones responsible for pathogenicity (Liu 
et al., 2010). In order to better understand the fate of E. coli, the application of molecular methods are needed which allow to detect microorganisms in different metabolic states including VBNC. Detection of bacteria which are able to elongate using, so called, direct viable count (DVC) (Kogure et al., 1979) in combination with fluorescence in situ hybridization (FISH) is one of the tools allowing to study VBNC bacteria.

In previous studies, to increase the probability of detecting E. coli, the composition of the biofilm was analysed (Juhna et al., 2007) The results showed that ca. $0.1 \%$ from total microbial population in the biofilm consist of $E$. coli even though no indicators of faecal contamination were found by routine sampling and analyses of water. In the present study the sampling of biofilm and large volumes of water (concentrates) from the networks over the period of two years was performed and total, cultivable and potentially dividing (detected as DVC-FISH) cells were analysed to obtain comprehensive data about the distribution of $E$. coli in water distribution networks. With this approach it was expected to detect even a low number of $E$. coli and, hence, better understand the fate of these faecal origin bacteria in the networks. The study was carried out in a large water distribution network (Riga, Latvia) meeting drinking water quality standards with respect to microbiology.

\section{Materials and methods}

\subsection{Site location and sampling}

The total length of Riga drinking water supply system is $1374 \mathrm{~km}$ with a demand of $1500 \mathrm{~L} \mathrm{~s}^{-1}$. The $76 \%$ of all pipe length consists of cast and ductile iron, $19 \%$ of steel and the rest of reinforced concrete and polyethylene (Rubulis et al., 2010). The left bank is supplied with two-stage treated surface water, whereas the right bank is supplied with groundwater treated by artificial groundwater recharge through infiltration. In both cases final chlorination is applied. Detailed parameters of the water can be found elsewhere (Tihomirova et al., 2010).

A total of 24 biofilm samples and 40 water samples were collected from eight sites at water treatment stations and four sites in Riga drinking water supply system (Latvia) (Fig. 1). Points were located at surface and groundwater treatment plants before and during treatment and just after final chlorination (S-RW, S-DW, G-RW, G-DW and G-DW') and at four places in the network (S-NET1, S-NET2, G-NET1, GNET2). Samples were collected over a period of two years and included all four seasons.

To collect the biofilm, a stainless steel biofilm collector containing five $3 \mathrm{~mm}$ diameter stainless steel coupons inserted into 25 to $40 \mathrm{~mm}$ pipes was attached to the distribution system and kept for two weeks to allow the biofilm formation. After two weeks the collectors were removed and immediately transported to the laboratory. Within two hours the biofilm was removed by ultrasonication for $2 \mathrm{~min}$ at $20 \mu \mathrm{A}$

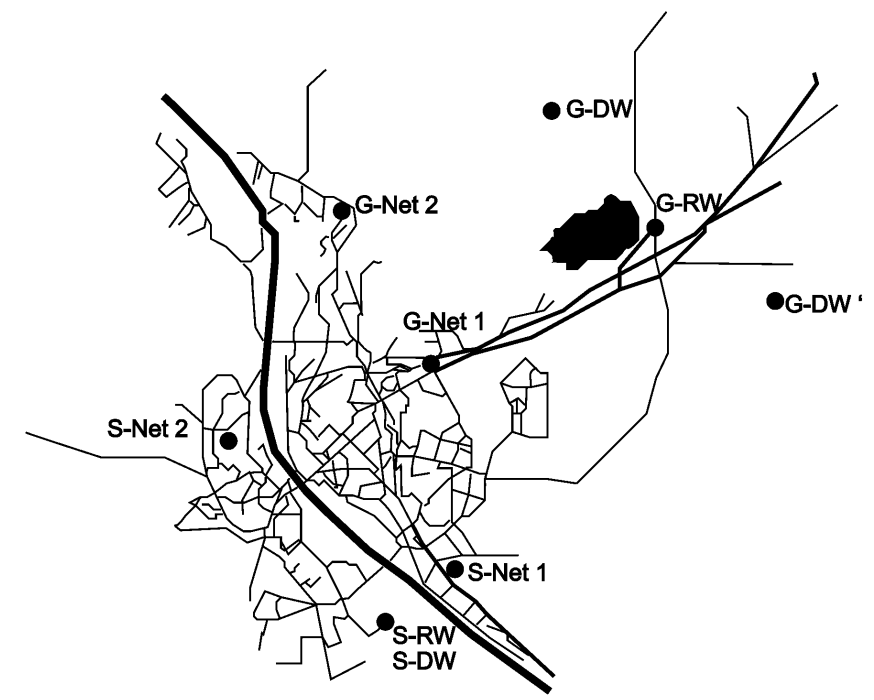

Figure 1. Riga drinking water distribution network with 9 biofilm and water sampling sites including water before (G-RW - raw lake water; S-RW - raw surface water) and after treatment (S-DW - surface water after final chlorination) and, G-DW (infiltrated groundwater after final chlorination) and in the network S-NET1, S-NET2, G-NET1 and G-NET2. Numbers 1 and 2 indicate the residence time after treatment - " 1 " having shorter residence time.

and $22 \mathrm{KHz}$. A total of $16-40 \mathrm{~mL}$ biofilm suspension in sterile distilled water was obtained and further analysed. All samples were analysed in double.

A large volume of water samples (more than $100 \mathrm{~L}$ ) were concentrated to approximately $1 \mathrm{~L}$ using tangential ultrafiltration method. Total concentration time varied from 12$24 \mathrm{~h}$. The apparatus used for concentration was similar to the one developed within TECHNEAU project. The estimated recovery rate for the concentration of drinking water was $81 \pm 33 \%$ (Veenendaal and Brouwer-Hanzens, 2007). The obtained concentrate was collected into sterile glass bottles, transported to the laboratory and analysed within two hours. All samples were analysed in triple.

\subsection{Total bacterial numbers (TBN)}

A known volume of sample $(\sim 0.1 \mathrm{~mL}$, adjusted to obtain 15-100 cells per microscope field of view) was filtered onto $25 \mathrm{~mm}$ diameter, $0.2 \mu \mathrm{m}$ pore-size filters (Anodisc; Whatman plc), fixed with 3-4\% $(v / v)$ formaldehyde and stained with $10 \mu \mathrm{g} \mathrm{mL}^{-1}$ DAPI (4',6-diamidino-2-phenylindole, Merck) for $15 \mathrm{~min}$. Cell numbers were determined by epifluorescence microscopy by counting 20 random fields of view (Ex. $340 / 380 \mathrm{~nm}$; Em. > $425 \mathrm{~nm}$, dichromatic mirror $565 \mathrm{~nm}$, Leica DM, LB). 
Table 1. Total cultivable, FISH positive and DVC positive (viable) Escherichia coli in the biofilm and water samples. Values are the average for four seasons with standard deviation specified as a maximum and minimum interval.

\begin{tabular}{lllll}
\hline Sampling site & $\begin{array}{l}\text { Sample } \\
\text { type }\end{array}$ & $\begin{array}{l}\text { Cultivable E. coli, } \\
\text { cfu cm }^{-2} \text { or cfu L }\end{array}$ & $\begin{array}{l}\text { FISH positive E. coli, } \\
\text { cells cm } \text { or cells L }^{-1}\end{array}$ & $\begin{array}{l}\text { DVC positive E. coli, } \\
\text { cells cm }\end{array}$ or cells L \\
\hline S-RW & W & 26.74 & n/d & $(2.52 \pm 0.17) \times 10^{3}$ \\
& B & 0 & $44.21 \pm 34.72$ & $1.99 \pm 2.54$ \\
S-DW & W & 0 & n/d & 0 \\
& B & 0 & $8.40 \pm 3.92$ & $2.95 \pm 5.14$ \\
S-NET1 & W & 0 & n/d & $0.93 \pm 1.61$ \\
& B & 0 & $111.58 \pm 57.87$ & $45.20 \pm 30.25$ \\
S-NET2 & W & 0.13 & n/d & $9.30 \pm 4.13$ \\
\hline G-RW & W & 30.24 & n/d & $(2.99 \pm 0.94) \times 10^{3}$ \\
& B & 0 & $9.39 \pm 1.67$ & $0.66 \pm 0.85$ \\
G-DW & W & 0 & n/d & $1.01 \pm 1.75$ \\
G-DW' & W & 0 & n/d & 0 \\
& B & 0 & $14.44 \pm 4.94$ & $3.54 \pm 4.79$ \\
G-NET1 & W & 0.06 & n/d & $0.94 \pm 1.62$ \\
& B & 0 & $70.62 \pm 19.97$ & $84.75 \pm 57.37$ \\
G-NET2 & W & $0.006 \pm 0.01$ & $103.97 \pm 20.05$ & $52.41 \pm 58.72$ \\
\hline
\end{tabular}

Values are the average for four seasons with standard deviation specified as a maximum and minimum interval.

${ }^{*} \mathrm{~W}$ - water, B - biofilm

** For biofilm samples the results are represented as cfu or cells per $\mathrm{cm}^{2}$, for water samples - cfu or cells per Liter of water. $\mathrm{N} / \mathrm{D}$ - not determined

\subsection{ATP measurements}

ATP was determined according to a modified method described by Vital et al. (2008). In brief, $500 \mu \mathrm{L}$ of pre-warmed sample were mixed with BacTiter-GloTM System (Promega, USA) and measured with luminometer. Results were expressed as ng ATP per $\mathrm{cm}^{2}$ of biofilm sample. For all samples total ATP and free ATP was measured and then cell ATP calculated. To obtain free ATP the sample was filtered through $0.1 \mu \mathrm{m}$ pore size syringe filters (Sartorious, Minisart ${ }^{\circledR}$, Germany).

\subsection{Culture based methods}

To obtain heterotrophic plate counts (HPC) samples were serially diluted in sterile distilled water and then inoculated onto R2A agar plates by spread plate technique. All plates were incubated in dark at $22^{\circ} \mathrm{C}$ for 7 days. Results were expressed as colony forming units (CFU) per $\mathrm{cm}^{2}$ (biofilm) or $\mathrm{ml}$ (water) of sample. For cultivable E. coli samples were analysed by membrane filtration method in a certified reference laboratory according to EN ISO 9308-1:2000 (ISO, 2001).

\subsection{DVC-FISH}

Cell viability-potential to divide, was determined by modified DVC method by Kogure et al. (1979) and combined with FISH. The validity of the FISH method used for detection of $E$. coli in this study has been proven earlier where it was compared with other molecular methods. In brief, sam- ples were mixed with equal amount of Tryptone Soya broth (Oxoid Ltd., UK) and $10 \mu \mathrm{g} \mathrm{mL} \mathrm{m}^{-1}$ nalidixic acid and incubated for $6 \mathrm{~h}$ at $30^{\circ} \mathrm{C}$. After the incubation, samples were fixed with $3-4 \%(v / v)$ formaldehyde for $20 \mathrm{~min}$. Then the samples were filtered onto $25 \mathrm{~mm}$ diameter, $0.2 \mu \mathrm{m}$ pore-size filters (Anodisc; Whatman plc) washed with sterile distilled water, removed from filtration device and air-dried. Then, $20 \mu \mathrm{L}$ of PNA hybridization mix consisting of hybridization buffer $(50 \mathrm{mM}$ Tris- $\mathrm{HCl}, 10 \% \mathrm{w} / v 50 \%$ dextran sulphate, $0.1 \mathrm{mM}$ of NaCl, $30 \% v / v$ formamide, $30 \% v / v$ tetra-sodium pyrophosphate, $0.2 \% \mathrm{w} / v$ polyvinylpyrrolidone, $0.2 \% \mathrm{w} / \mathrm{v}$ Ficoll 400, $5 \mathrm{mM} \mathrm{Na}_{2}$ EDTA, 0.1\% v/v Triton X-100) and $200 \mathrm{nM}$ fluorescently labelled PNA probe, was applied to the filters and covered with cover glass. The PNA probe (TCA ATG AGC AAA GGT) (Perry-O'Keefe et al., 2001) was labelled with CY3 (Ex: 550, Em: 570) and flanked with solubility enhancers (Applied Biosystems, Foster City, CA, USA). The samples were incubated at $57^{\circ} \mathrm{C}$ for $60 \mathrm{~min}$ in a tight vessel in dark. After hybridization the filters were washed with plenty of sterile distilled water, air-dried and visualized with epifluorescence microscopy (Ex. $535 \pm 25 \mathrm{~nm}$; Em. $610 \pm 37 \mathrm{~nm}$, dichromatic mirror $565 \mathrm{~nm}$, Leica DM LB). The detection limits were calculated based on volume of analysed sample, repetitions made and microscope fields of view examined. In this study filter sectors were scanned for positive events, enabling to overview $1 / 5$ of the filter surface (Mezule, 2012). The calculated limits for E. coli was 6 cells per $\mathrm{mL}$ in concentrated water or 4 cells per $\mathrm{cm}^{2}$ in the biofilm. 
Table 2. Total bacterial numbers (TBN) and heterotrophic plate counts (HPC) in the biofilm samples.

\begin{tabular}{|c|c|c|c|}
\hline Sampling site & $\mathrm{TBN}$, cells cm $\mathrm{cm}^{-2} \times 10^{6}$ & $\mathrm{HPC}, \mathrm{cfu} \mathrm{cm}^{-2} \times 10^{4}$ & $\% \mathrm{HPC}$ \\
\hline S-DW & $5.64 \pm 7.62$ & $4.04 \pm 5.33$ & 0.72 \\
\hline S-NET 1 & $3.17 \pm 3.88$ & $8.40 \pm 11.89$ & 2.65 \\
\hline S-NET 2 & $17.13 \pm 24.90$ & $41.51 \pm 21.62$ & 2.42 \\
\hline G-DW & $1.12 \pm 0.48$ & $0.78 \pm 1.44$ & 0.7 \\
\hline G-NET 1 & $7.71 \pm 10.35$ & $3.14 \pm 2.71$ & 0.41 \\
\hline G-NET 2 & $28.97 \pm 18.14$ & $178.50 \pm 49.82$ & 6.16 \\
\hline
\end{tabular}

Values are the average for all biofilm samples tested during four seasons with standard deviation specified as a maximum and minimum interval.

\section{Results and discussion}

Previous studies have shown that E. coli is harboured in drinking water biofilm in a nonculturable form (Juhna et al., 2007). In this study we sampled both water and biofilm at several distances away from water treatment plants to understand if the number these bacteria is changing with increase of water residence time. Water supply system (Riga, Latvia) which meets European Drinking Water Directive (98/83/EC) with respect to microbial parameters was selected for study. Analyses of raw water samples (river and groundwater) with standard methods (based on sample cultivation on growth media) showed that water sources contained less than four cultivable E. coli per $100 \mathrm{~mL}$ of sample (Table 1), which is an indication of relatively clean surface water. In contrast, DVC-FISH analyses showed that viable E. coli cell concentration was about 10 times higher. This is in agreement with previous studies about raw waters (Garcia-Armisen and Servais, 2004) which showed that only a fraction of alive $E$. coli are detected with traditional methods in raw water sources used for drinking water production.

Analyses of drinking water after treatment and in the distribution network showed that none of water samples exceeded the standard value of zero cultivable $E$. coli in $100 \mathrm{~mL}$. The applied sample concentration method allowed to decrease the detection limit when compared to traditional sampling methodology. About $30 \%$ of water samples contained 0.02 to 1.2 cells in $10 \mathrm{~L}$. All positive samples were obtained further in the networks (S-NET2, G-NET1 and GNET2) rather than directly after water treatment. Hence, cultivable $E$. coli cells were present in drinking water, however, the concentration was very low to be detected with traditional sampling and analytical methodology. The analyses of water samples showed that the lowest amount of FISH positive cells was obtained from water samples (G-DW and S-DW) directly after the treatment plants (Table 1) and this number tended to increase further in the network. The same trend was observed also for viable E. coli (DVC-FISH positive) cells, where their concentration increased from few cells to more than 50 cells per litre as water proceeded into the networks.

The analyses of biofilm samples showed that at the treatment plant (S-DW) as much as $44 \mathrm{E}$. coli cells per $\mathrm{cm}^{2}$ were

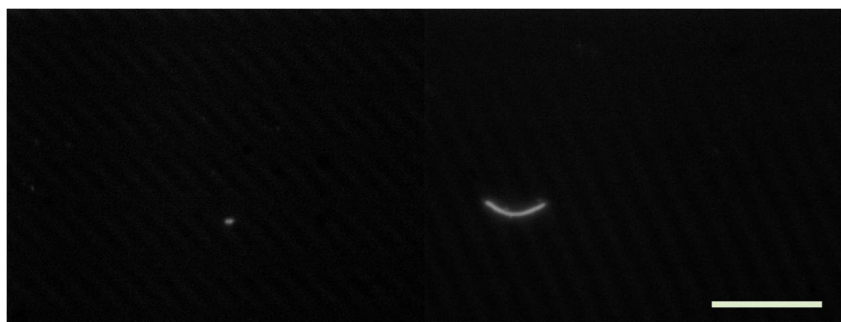

Figure 2. G-DW biofilm sample obtained in winter season with FISH positive E. coli (left) and DVC-FISH positive E. coli (right) Bar $10 \mu \mathrm{m}$.

present. This particular measurement could be biased by high background fluorescence intensity from humic substances present in the water (Tihomirova et al., 2010). However, the interference from autofluorescent background was overcome by analysing the viable cells with DVC-FISH as in this case the bacterial cells appeared very bright and visible due to their increased size (Fig. 2). The amount of viable E. coli in the biofilm at the treatment plant was 1.99 cells $\mathrm{cm}^{-2}$ (S-DW) and 0.66 cells $\mathrm{cm}^{-2}$ (G-DW) indicating that faecal bacteria sporadically can pass though the treatment plant and are harboured within the biofilm. A significant increase $(p<0.03)$ in DVC-FISH counts was observed when treated (both surface and ground) water was compared to (NET) sites in the networks. In total the results of FISH analyses showed that each $\mathrm{cm}^{2}$ of two week old biofilm contain a minimum of 5 $E$. coli cells (Table 1) and all 24 biofilm and 25 water samples were positive for $E$. coli. From all FISH positive $E$. coli in the biofilm, on average $53 \%$ of cells showed the ability to divide.

Along with cell distribution trends, the influence on seasonality was analysed and showed that there is no significant difference $(p>0.05)$ in sampling time for DVC-FISH. Again, irrespective of the season, the highest amount of DVC positive $E$. coli was observed for points further in the network. For total E. coli counts significantly different results were obtained in 2 sites - S-DW $(p<0.02)$ and S-NET1 $(p<0.05)$ where in winter and spring months, respectively, higher counts were obtained, indicating that warmer outside temperatures are not linked to the occurrence of $E$. coli in the network, especially when the water temperature in the system is around $13^{\circ} \mathrm{C}$ throughout the year.

The findings of faecal bacteria in the drinking water is not so surprising since previous research has shown that $E$. coli can survive in the drinking water biofilters (Li et al., 2006) and even multiply in the biofilm (Camper et al., 1991; Fass et al., 1996; Williams and Braun-Howland, 2003). Our study confirmed that the biofilm act as a source for accumulation and possible growth of $E$. coli in drinking water distribution networks. This should be taken into account when studying the fate of these bacteria from the source to the tap. 
The highest amount of E. coli was found in the samples collected further away from both water treatment plants (Table 1). There was no correlation between cultivable and viable E. coli numbers in drinking water, unlike observed for raw water samples (Garcia-Armisen and Servais, 2004). Similarly the biofilm in locations further away in the network contained more $E$. coli cells with a higher percentage of DVC positive ones. The high numbers of $E$. coli could be due to their resistance to chlorine, low chlorine levels at all in the network or low protozoan grazing (Sibille et al., 1998). Their release from the biofilm by detachment (Parsek and Singh, 2003) can have a serious effect on human health, especially if VBNC forms of bacteria, including E. coli $\mathrm{O} 157: \mathrm{H} 7$ are present (Liu et al., 2009). Moreover, lately discussions about the existence of naturalized $E$. coli, although no pathogenicity was proven, raise concerns about secondary contamination of water supply systems due to pathogenic bacteria regrowth (Jjemba et al., 2010).

The particular water supply system is known to support bacterial growth due to the high level of labile organic carbon in drinking water (Tihomirova et al., 2010). Thus, biofilm formation was also studied. The analysis of coupon samples inserted in Riga drinking water distribution network showed that extensive biofilm formation occurred on surfaces just at the outlet from the treatment plant, reaching the concentration of more than $10^{6}$ bacterial cells per $\mathrm{cm}^{2}$ of the biofilm (Table 2).

The amount of total bacteria, heterotrophic plate counts and $E$. coli in the biofilm tended to increase with the water residence time in the network. A positive correlation $\left(R^{2}>0.95\right)$ between the total bacterial numbers and heterotrophic plate counts in the biofilm was obtained. For groundwater supply the percent of cultivable bacteria in the biofilm increased from $<1 \%$ just after treatment to more than $6 \%$ at G-NET2 site (Table 2), indicating on the formation of more favourable conditions for microbial colonization and growth. Similar increase in the distribution network was also observed for water samples, where a correlation of $R^{2}=0.8869$ was obtained between HPC and TBN in five water samples from one sampling site. But, similarly as in previous studies, no correlation between total bacterial counts or HPC in biofilm and water was observed (Flemming, 2002). In water samples from both treatment plants the bacterial numbers tended to increase with the water residence time in the network. This has been observed previously (Juhna et al., 2007) and could be connected to decrease of disinfectant in the network in addition to increase of bacterial resistance and survival capacity (Gilbert and Brown, 1995; LeChevallier and Kwok-Keung, 2004; Saby et al., 2005). Thus, more favourable conditions for biofilm formation and maturing are created.

The results of ATP showed a high variation between the samples (from 1.1 till $2518 \mathrm{ng}$ ATP $\mathrm{mL}^{-1}$ ) and between the different seasons of samples from one location (7.35 till

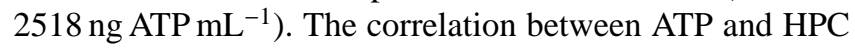

or TBC was weak, which is similar to previous observations (Delahaye et al., 2003). Comparison of DVC positive E. coli with total bacterial counts showed a linear correlation $\left(R^{2}=0.9637\right)$ in the biofilm, thus, indicating on the role of biofilm community on pathogen accumulation. Most of the studies that have examined the presence of $E$. coli in biofilms have used culture-based assays (Castonguay et al., 2006; Hu et al., 2005) which have limitations, including the duration of incubation, antagonistic organism interference, lack of specificity, and poor detection of slow-growing or non-dividing microorganisms (Rompre et al., 2002). Plate count methods also result in some inaccuracy since the cells can be clumped together and intertwined with other biofilm components. It must be emphasized that methods using microbial growth will not detect non-dividing cells at all. Therefore, the number of $E$. coli in the drinking water distribution network could be, and likely is, underestimated. The presence of $E$. coli was inadequately indicated by the traditional culture-based methods in the present study, a finding in agreement with previous studies showing that cultivation-independent detection methods detect at least 10 times more cells (Bjergbaek and Roslev, 2005).

This study has shown that analyses with culture based methods does necessary describe transport of $E$. coli in drinking water distribution system. We have shown that low number of these bacteria can pass though the treatment plant into the networks and accumulate on the surfaces of the pipes in a biofilm. Since no major outbreaks were detected in the water supply system studied, the link between a low number of E. coli and infections from drinking water cannot be ruled out. However, the findings raise questions about the margin of safety provided by conventional drinking water microbial quality control methods. Further studies should be directed to address this issue.

\section{Conclusions}

The combination of biofilm sampling, and water sample preconcentration and analyses of different viability forms revealed new information about behaviour of $E$. coli in drinking water systems. Despite that both treatment processes are generally regarded as safe, some sporadic breakthrough of $E$. coli occur which lead to small numbers of $E$. coli missed in drinking water when analysed with traditional sampling methodology. Total and viable amount of E. coli tend to accumulate in the networks were it is less exposed to disinfectant. Thus, biofilm formation in the drinking water distribution networks increases the risk (at least during the first two weeks) of accumulation of viable but non cultivable $E$. coli and their presence does not necessary directly links to recent faecal contamination. 
Acknowledgements. This work has been undertaken as a part of the research project "Technology enabled universal access to safe water - TECHNEAU" (Nr. 018320) which is supported by the European Union within the 6th Framework Programme. There hereby follows a disclaimer stating that the authors are solely responsible for the work. It does not represent the opinion of the Community and the Community is not responsible for any use that might be made of data appearing herein.

Edited by: I. Worm

\section{References}

Asakura, H., Ishiwa, A., Arakawa, E., Makino, S., Okada, Y., Yamamoto, S., and Igimi, S.: Gene expression profile of Vibrio cholerae in the cold stress-induced viable but non-culturable state, Environ. Microbiol., 9, 869-879, 2007.

Ashbolt, N. J., Grabow, W. O. K., and Snozzi, M.: World health organization (WHO). Water quality: Guidelines, standards and health, in: Indicators of microbial water quality, edited by: Fewtrell, L. and Bartram, J., IWA Publishing, London, 2001.

Bjergbaek, L. A. and Roslev, P.: Formation of nonculturable Escherichia coli in drinking water, J. Appl. Microbiol., 99, 10901098, 2005.

Bogosian, G., Morris, P. J. L., and O'Neil, J. P.: A mixed culture recovery method indicates that enteric bacteria do not enter the viable but nonculturable state, Appl. Environ. Microbiol., 64, 1736-1742, 1998.

Camper, A., McFeters, G., Characklis, W., and Jones, W.: Growth kinetics of coliform bacteria under conditions relevant to drinking water distribution systems, Appl. Environ. Microbiol., 57, 2233-2239, 1991.

Castonguay, M. H., van der Schaaf, S., Koester, W., Krooneman, J., van der Meer, W., Harmsen, H., and Landini, P.: Biofilm formation by Escherichia coli is stimulated by synergistic interactions and co-adhesion mechanisms with adherence-proficient bacteria, Res. Microbiol., 157, 471-478, 2006.

Delahaye, E., Welte, B., Levi, Y., Leblon, G., and Montiel, A.: An ATP-based method for monitoring the microbiological drinking water quality in a distribution network, Water Res., 37, 36893696, 2003.

Fass, S., Dincher, M. L., Rasoner, D. J., Gatel, D., and Block, J.C.: Fate of Escherichia coli experimentally injected in a drinking water distribution pilot system, Water Res., 30, 2215-2221, 1996.

Flemming, H. C.: Biofouling in water systems - cases, causes and countermeasures, Appl. Microbiol. Biot., 59, 629-640, 2002.

Garcia-Armisen, T. and Servais, P.: Enumeration of viable E. coli in rivers and wastewaters by fluorescent in situ hybridization, J. Microbiol. Meth., 58, 269-279, 2004.

Gilbert, P. and Brown, M.: Phenotypic plasticity and mechanisms of protection of bacterial biofilms from antimicrobial agents, in: Microbial biofilms, edited by: Lappin-Scott, H. E. C., and Costerton, J. W., Cambridge University Press, 118-132, 1995.

Hu, J., Yu, B., Feng, Y., Tan, X., Ong, S., Ng, W., and Hoe, W.: Investigation into biofilms in a local drinking water distribution system, in: Biofilms, Cambridge University Press, Cambridge, 19-25, 2005.
Hunter, P. R.: Waterborne disease: Epidemiology and ecology, John Wiley and Sons, West Sussex, 1997.

ISO 9308-1:2000: Water quality - detection and enumeration of Escherichia coli and coliform bacteria - Part 1: Membrane filtration method, International Organisation for Standartization, 2001.

Jjemba, P. K., Weinrich, L. A, Cheng, W., Giraldo, E., and LeChevallier, M. W.: Regrowth of potential opportunistic pathogens and algae in reclaimed-water distribution systems, Appl. Environ. Microbiol., 76, 4169-4178, 2010.

Juhna, T., Birzniece, D., Larsson, S., Zulenkovs, D., Sharipo, A., Azevedo, N. F., Ménard-Szczebara, F., Castagnet, S., Féliers, C., and Keevil, C. W.: Detection of Escherichia coli in biofilms from pipe samples and coupons in drinking water distribution networks, Appl. Environ. Microbiol., 73, 7456-7464, 2007.

Kogure, K., Simidu, U., and Taga, N.: A tentative direct microscopic method for counting living marine bacteria, Can. J. Microbiol., 25, 415-420, 1979.

LeChevallier, M. W. and Kwok-Keung, A.: Water treatment and pathogen control: Process efficiency in achieving safe drinking water, IWA Publishing on behalf of the World Health Organization, London, 2004.

Lee, S. H., Levy, D. A., Craun, G. F., Beach, M. J., and Calderon, R. L.: Surveillance for waterborne-disease outbreaks - United States, 1999-2000, MMWR Surveill Summ, 51, 1-47, 2002.

Li, J., McLellan, S., and Ogawa, S.: Accumulation and fate of green fluorescent labeled Escherichia coli in laboratory-scale drinking water biofilters, Water Res., 40, 3023-3028, 2006.

Liu, Y., Wang, C., Tyrrell, G., Hrudey, S. E., and Li, X. F.: Induction of Escherichia coli $\mathrm{O} 157: \mathrm{H} 7$ into the viable but non-culturable state by chloraminated water and river water, and subsequent resuscitation, Environ. Microbiol. Rep., 2, 155-161, 2009.

Liu, Y., Wang, C., Tyrrell, G., and Li, X. F.: Production of Shigalike toxins in viable but nonculturable Escherichia coli O157:H7, Water Res., 44, 711-718, 2010.

Mezule, L.: Significance of nonculturable Escherichia coli in drinking water: experimental and pilot studies in large drinking water systems, Lambert Academic Publishing, 2012.

Na, S. H., Miyanaga, K., Unno, H., and Tanji, Y.: The survival response of Escherichia coli K12 in a natural environment, Appl. Microbiol. Biot., 72, 386-392, 2006.

Oliver, J. D.: Recent findings on the viable but nonculturable state in pathogenic bacteria, FEMS Microbiol. Rev., 34, 415-425, 2010.

Parsek, M. and Singh, P.: Bacterial biofilms: An emerging link to disease pathogenesis, Annu. Rev. Microbiol., 57, 677-701, 2003.

Perry-O'Keefe, H., Stender, H., Broomer, A., Oliveira, K., Coull, J., and Hyldig-Nielsen, J.: Filter-based PNA in situ hybridization for rapid detection, identification and enumeration of specific microorganisms, J. Appl. Microbiol., 90, 180-189, 2001.

Rompre, A., Servais, P., Baudart, J., de-Roubin, M., and Laurent, P.: Detection and enumeration of coliforms in drinking water: Current methods and emerging approaches, J. Microbiol. Meth., 49, 31-54, 2002.

Rubulis J., Dejus S., and Meksa, R.: Online measurement usage for predicting water age from tracer tests to validate a hydraulic model, 12th Annual Water Distribution Systems Analysis Conference, Arizona, Tucson (USA), 2010.

Saby, S., Vidal, A., and Suty, H.: Resistance of Legionella to disinfection in hot water distribution systems, Water Sci. Technol., $52,15-28,2005$. 
Scheusner, D. L., Busta, F. F., and Speck, M. L.: Inhibition of injured Escherichia coli by several selective agents, Appl. Microbiol., 21, 46-49, 1971.

Sibille, I., Sime-Ngando, T., Mathieu, L., and Block, J. C.: Protozoan bacterivory and Escherichia coli survival in drinking water distribution systems, Appl. Environ. Microbiol., 64, 197-202, 1998.

Tihomirova, K., Rubulis, J., and Juhna, T.: Changes of nom fractions during conventional drinking water treatment process in Riga, Latvia, Wa. Sci. Technol., 10, 157-163, 2010.

van Lieverloo, J. H., Mesman, G. A., Bakker, G. L., Baggelaar, P. K., Hamed, A., and Medema, G.: Probability of detecting and quantifying faecal contaminations of drinking water by periodically sampling for E. coli: A simulation model study, Water Res., 41, 4299-4308, 2007.
Veenendaal, H. R. and Brouwer-Hanzens, A. J.: A method for the concentration of microbes in large volumes of water, in: D 3.2.4, TECHNEAU, 1-30, 2007.

Vital, M., Hammes, F., and Egli, T.: Escherichia coli O157 can grow in natural freshwater at low carbon concentrations, Environ. Microbiol., 10, 2387-2396, 2008.

Williams, M. M. and Braun-Howland, E. B.: Growth of Escherichia coli in model distribution system biofilms exposed to hypochlorous acid or monochloramine, Appl. Environ. Microbiol., 69, 5463-5471, 2003. 